\title{
Cultura de massas e representações femininas na paulicéia dos anos 20
}

\author{
Maria Inez Machado Borges Pinto
}

Departamento de História/FFLCH-USP

\section{RESUMO}

Era muito claro que as mulberes estavam reelaborando seuspapéis dentro da sociedade moderna. As revistas de fãs, ocinema e a publicidadeapresentavam repetidamente artigose imagens sobre jovens muIherese as identificavam com ajuventude e a modernidade emsi. Este artigoanalisacomoaculturademassas, especialmente ocinema, apelavapara a construçãodessaimagem feminina comocoroláriodamodernidade pois ela se opunba frontalmenteàsmulberesdolarprovinciano, arcaico, erepresentava antes de tudo a mulbermoderna, que trabaIhafora eque participa ativamente davidapública.

Palavras-Chaves: Cultura de Massas; Representaçöes Femininas; $U r$ banização; Modernidade.

\section{ABSTRACT}

It was clear that women were reelaboration their roles out in the modern society. The magazines, the movies and the publicity introduzed repeatedly articles and images about young women, identifying them with youth and modernity. This article analyses bow the mass culture, specially the movies appeals to this female image like corollary of modernity, that opposes directly to the provincial and archaic bousewifes, representing before anything else the moderm women who bas a job and takes part in the political life. Keywords: Mass Culture; Female Representations; Urbanization, Modernity.

São Paulo, na década de 20, passava por transformações de todas as naturezas: econômicas, sociais, administrativas e principalmente culturais. Seu semblante não era totalmente conbecido pois ainda se formava, apoiado, por um lado na influência do modelo civilizador e modernizador da Belle Époque européia particularmente a francesa-e de outro numa sólida berança cultural, advinda das nossas raízes coloniais. 
Adespeito do processo de "regeneração", caracterizado pela reforma urbana do Rio de Janeiro, pela modernizaçáo do porto, pela campanha saneadora da vacina obrigatória e pela Grande Exposição Nacional; frente à condenação dos hábitos e costumes $l i$ gados pela memória à sociedade tradicional; a negaçáo de todoe qualquer elemento de cultura popular que pudesse macular a imagem civilizada da sociedade dominante; uma política rigorosa de exclusão dos grupos populares da área central da cidade e um cosmopolitismo profundamente identificado com a vida parisiense. Oque se via em São Paulo na mesma época era um quadrosimilar, embora impregnado de especificidades devido ao empenbo das elites locais, mergulbadas num universo de imigrantes de múltiplas nacionalidades em buscar uma mítica identidade regional empreendedora.

(...) São Paulo era uma correria sôfrega para escavar raízes tradicionais e restabelecer uma 'memória' de tinturas coloniais; um empenho pelo resgate e identificação com uma cultura popular, mormente de recorte 'sertanejo'; uma busca de áreas periféricas ao centro, à procura dos espaços livres para corridas e esportes, dopública para asfaçanbas e da animaçãopopularpara o Carnaval e as novas celebrações; e um curioso modernismo parisiense, que ensinava a desprezar a vellha Europa moribundae a amarapujançadaAmérica ${ }^{1}$.

A cidade de Sáo Paulo era caracterizada por um cosmopolitismocontraditório marcado pelostensionamentos advindos da coexistência de diferentestemporalidades, onde conviviam lado a lado nas produçóes e reproduçóes da vida cotidiana o arcaico e o moderno, o novo e o velbo, configurando diversos ritmos sociais que imprimiam à cidade uma feição beterogênea. Nos anos 20, São Paulo "encarnava a imagem de uma metrópole inacabada, moderna e provinciana, de um país periférico, das enchentes e da pobre$z a^{\prime 2}$, equilibrando-se entre um modelo europeu de urbanidade $e$ a convivência inventiva e improvisada entre inúmeras etniase entre os novos grupos sociais que se formavam.

(...) Afinal, São Paulo não era uma cidade nem de negros, nem de brancos e nem de mestiços; nem de estrangeiros e nem de brasileiros; nem americana, nem européia, nem nativa; nem era industrial, apesar do volume crescente dasfábricas, nem entreposto 
agrícola, apesar da importância crucial do café; não era tropical, nem subtropical; não era ainda moderna, masjá não tinba mais passado. Essa cidade que brotou súbita e inexplicavelmente, como um colossal cogumelo depois da chuva, era um enigma para seus próprioshabitantes, perplexos, tentando entendê-lo comopodiam, enquanto hutavam para nãoserem devorados 3 .

Em 1920, ovalor da produção paulista passava da metade da produção geral da União. São Paulo era a "locomotiva carregando atrás de si vinte vagóes vazios", como se dizia então. O ritmo das transformações se acelera. Há uma expansão borizontal na cidade que deslinda novos bairros enquanto os antigos se remodelam, no centro apontam os primeiros prédios; São Paulo pela primeira vez conbece, nos anos 20, um rush imobiliário, marcado pela especulação de terrenos. Sáo Paulo civiliza-se. Freqüenta escolas, clubes, cafés-concerto, teatros e cinemas. Movimenta-se ao ritmo dos maxixes e dos sambas, dos ragtimes, one-steps e tangos. Os salóes burgueses se aristocratizam, recobrem-se de savonneries e móveis franceses; além de professores de música. É todo refinamento de uma cultura urbana e burguesa que se estrutura e se irradia pelas classes médias'.

Ascamadasmédiasiam consolidando-se, agregandotraballsadores dos setores ferroviário e dos serviços urbanos, como empresas de energia, transportes, água, telefone, comércio importador e construçáo civil, que cresciam junto com a cidade. Engrossavam as camadas médias, os pequenos proprietários rurais empobrecidos que, na cidade, passaram a ocupar os cargos mais elevados do aparelho burocrático ou tornaram-se profissionais liberais. Os brasileiros de origem mais pobre e os imigrantes ocupavam os cargos inferiores no funcionalismo público, nos serviços de escritório, nos setores bancário, industrial, comercial e no mercado informal de trabalbo5.

Aolado desta, paralela e desapercebida, uma subcultura surge e se desenvolve: um esboço da cultura operária, amálgama disforme de elementos estrangeiros, nacionais, rurais e urbanos, que cresce nos bairros pobres da cidade, nas bottegue do Brás, nas vielas do Bexiga, nos cortiços da Barra Funda. Esta "cultura operária" aburguesa-se e é absorvida pela avalanche da "cultura de massas", sofrendo um processo constante de reelaboração. 
No "ponto de encontro entre aquelas duas culturas, a burguesa que se generaliza e a popular que é reelaborada; produtobíbrido do contato de bomens como Antônio de Souza Campos, Plínio de Castro Ferraz, Menotti del Picchia, Canuto Mendes de Almeida, formados na cultura burguesa, com outros bomens como Gilberto Rossi, Arturo Carrari, Nino Ponti, portadores do espírito do Brásnasce o cinema mudo paulista". Estes entrecruzamentos entre cultura burguesa e cultura popularnáo devem ser entendidoscomo relaçóes de exterioridade entre dois conjuntos estabelecidos de antemáo e sobrepostos mas "como produtores de ligas culturais e intelectuais cujos elementos se encontram tão solidamente incorporados uns aos outros como nas ligas metálicas".

A essas transformaçóes sociais e urbanas correspondia uma nova experimentação do viver na cidade. São Paulo transformava-se numa metrópole moderna, ainda que contraditória, cuja principal característica era a de ser um espaço ao mesmo tempo arregimentador efragmentário, convidativo e ameaçador, “(...) a metrópole moderna recebe uma representação ambivalente como

142 olocal de origem de um caos avassalador a matriz de uma nova vitalidade emancipadora's.

Em meio a esse panorama, imagens de cunbo futurista alinham-se ao longo de inúmeros textos de propaganda de uma São Paulo moderna, propondo equivalências objetivas entre a cidade, a modernidade e uma nova cultura. Numa sobreposição otimista e freqüentemente acrítica, destacam-se "as visóes da cidade tentacular, da cidade em crescimento, da cidade industrial, da cidade, enfim moderna, à qual nãofalta nenbum dos atributos exteriores que definem o processo de modernização acelerado desde o início do século $X X^{\prime \prime}$.

Na visáo dos modernistas como Oswald de Andrade, Guilherme de Almeida, Menotti del Picchia, a cidade era definida pela sua audaciosa verticalização, suas ruas de fábricase seus conjuntos de palácios americanos, destacando-se o caráter de "metrópole febril, milionária, imprevistamente enorme”. Essa visão futurista é também característica marcante da percepção do poeta Blaise Cendrars, que transforma São Paulo no epítome do espírito moderno, na concretização da "cidade futurista", ritmada 
pelo trânsito, pelas multidóes, caracterizada por um paisagem artificial, na qual soam buzinas e piscam letreiros"10.

Existia, por parte dos modernistas, o afá propagandístico da modernidade, dos novos modos de vida nessa metrópole americana e da construção da figura de um novo bomem, cosmopolita e atualizado, diferente do tipo brasileiro convencional. Assim, Peri e Jeca Tatu são resquícios de uma minoria agonizante, fadados a desaparecer diante do surgimento de tipo definitivo do brasileirovencedor: forte, vivo, culto, inteligente, audaz, fruto de muitas raças em combate, resultante de muitos sangues e adaptado.

Menotti del Picchia era um entusiasta da imagem beróica da modernidade de São Paulo, recorrendo à visão modernista da cidade e do homem moderno, usando para isso toda sorte de recursos retóricos. Em artigos como "Matemos Peri!"11 $e$ "Peri" Menotti desfecha um ataque virulento contra "nosso absurdo e ingênuo amor pelo passado, que mata as aspirações de fórmulas novas - na política, na economia, na finança, na ética, na literatura". Como bem observa Annateresa Fabris, Menotti, "em seu ataque aos resquícios do passado - romantismo, regionalismo, parnasianismo - deixa transparecer uma concepção não apenas estética, mas social e racial (...) Para negar o tripé racial brasileiro e para opor-llhe a visão do paulista cosmopolita, bomem de ação, pragmatista ativo"13.

Afigura bistórica do bandeirante é transposta e aplicada aosfazendeiros, aos industriais, aos "criadores de fortuna", aos self-made, isto é, àqueles "indivíduos práticos, de gênio claro e positivo", que se erguem como contraponto aos "gramáticos e bacharéis", aos "críticos e doutores" que pululam pelo resto do país ${ }^{14}$. Para os entusiastas da arte nova, sequiosos de destacaro papel da Paulicéia no contexto brasileiro e até mesmolatino-americano, não é difícil construir um imenso caleidoscópio, uma montagem de fatos e sensaçóes que estruturam um retrato eloqüente de um fenômeno inédito para a nação.

Assim, segundo as perspectivas modernistas e a despeito da sua beterogeneidade -que nos desvenda nuances, quase que uníssonas-sobre a interpretação e a representação dessa modernidade forjada no interior de seus discursos; se o Rio de Janeiro era a 
capital política, São Paulo configura-se nitidamente como a cidade da construção, avessa aos velhos cenários e aos velhos costumes do Brasil oitocentista e rural. Dessa forma, a cidade encontra expressáo em imagens fortemente conotadas com a modernidade, com seus ritmos, com sua efervescência, constituindo um painel em que não há lugar para dúvidas e hesitações e sim tão-somente para a visáoprospectiva, para a "vocaçãofuturista" de um "povode mil origens, arribado em mil barcos, com desastres e ânsias"15.

De fato, oprocesso modernizador trouxe consigo a racionalização de condutas, a proposta de bomogeneização de costumes e de consumo, ao mesmo tempo que a multiplicação das escalas do ambiente urbano tinha como contrapartida o encolbimento da figura bumana e a projeçáo da coletividade como um personagem em si mesmo, anunciando o surgimento da sociedade de massa. A partir do final do século XIX, as funções de socialização foram transferidas do âmbito mais íntimo e privativo para a esfera pública, seja pela ação do Estado, das corporaçóes empresariais, seja pela influência da imprensa, da publicidade, do cinema e outros meios de comunicação de massa. Com isso, uma subjetividade formada no âmbito das atividades de lazer e do consumismo cultural, numa "esfera pública que passa a assumir ela mesma formas de intimidade" é a conseqüência desse processo ${ }^{16}$. Dessa forma, as subjetividades se formam nos espaços de convivência coletiva enquanto que as opinióes e os comportamentos privados sãoformados no âmbito público.

Temos assim um quadro revelador da nova sensibilidade que se vai definindo na cidade e crescendo em escala fenomenal. Manifesta-se a natureza especialmente forte e coesiva das experiências de ação coordenada coletiva, envolvendo multidóes de indivíduos que, embora estranbos entre si, submetem-se a um mesmo conjunto de motivaçóes e estímulos para a ação. "Ofato de serem estranhos que adquirem uma nova identidade capaz de exaltálos e libertá-los, graças a uma fonte externa e artificial de incitamento, é que faz dessa experiência algo diverso dos rituais tradicionais e típico da nova ambiência metropolitana"17.

Ao lado de automóveis, bondes e luzes das ruas, os interiores servem de palco para o desenvolvimento de novos espetácu- 
los e atrações. Estes, na sua composição de movimento, luz, ruído e música, guardam uma correspondência com a agitação de estímulos lá de fora. No interior dessa agitação, “o cinema foi, durante certo tempo, uma novidade entre outras tantas, fazendo parte do conjunto de espetáculos que mobilizavam os mais diversos aparelhos e mecanismos, onde cérebro bumano e eletricidade combinavam-se para mostrar algo novo a espectadores em busca de novas atraçóes"'s.

O crescimento das indústrias e a produção em larga escala de produtos para abastecer essa sociedade de consumo emergente fez surgir ainda um outro morador dessa cidade: o operário. As fábricas eram os locais onde um número cada vez maior de pessoas passava a maior parte de seu tempo, vendendo sua força de traballo em troca do que mais tarde seria gasto nofeérico mercado de consumo de produtos baratos. A contrapartida dessa escala industrial estava nas ruas: as greves, a agitação social, as conspiraçóes, a "figura soturna do terrorista real e manipulada".

Mas não eram só os empresários e os operários que vinham alterar de forma irreversível a estrutura social e o quadro político vigentes: "(...) nas áreas de expansão mais recente da fronteira do café, o 'novo oeste' e a 'alta-mogiana', rapidamente se tornaram as mais produtivas, predominavam os pequenos e médios fazendeiros, na sua grande maioria de origem imigrante"19. Assim, a velha ordem social desfigurava-se para assumir novasfeiçóes.

Osurgimento, ainda que incipiente, de camadas médias cuja atividade profissional podia gerar um rendimento capaz de manter um consumo superior ao mínimo necessário para a sobrevivência, somado à disposiçấo de nossas elites e esses setores emergentes em adotar um estilo de vida urbano, possibilitou à cidade de Sáo Paulo o incremento da vida urbana e a intensificação dos bábitos de consumo, fatores que caracterizavam a civilidade e a modernizaçáo na época. Para acompanbar essemundodemudanças rápidas, proporcionadas pelo avanço cada vez maior da tecnologia, das fábricas e de seus apitos, fazia-se mister que astecnologias de lazer avançassem na mesma direçãose quisessem atrair mais consumidores para seu mercado, devendo adaptar-se àspoucashoras de lazer que restavam aobomem moderno. 
Logo que surge o cinema de destaca. Superando em interesse os espetáculos congêneres, torna-se crescentemente diversificado em suas características. É um fato intencional, chega aqui e ali, numa expansão que, de início, não carrega ainda sua dimensão monopolística. Mas, no momento em que se aproxima a Primeira Guerra Mundial, já desenvolve mais decisivamente seu caráter industrial, afastando-se cada vez mais de uma configuração semi-artesanal e local da produção. A partir daí, a posse de capitais, o domínio de condiçóes tecnológicas e de canais de distribuição, ao lado da crescente organização dos centros produtores, leva à estratização de um mercado internacional onde ficam nitidamente delimitados os papéis dos vários contextos nacionais. A divisáo entre exportadores e importadores de filmes adquire os contornos gerais de um sistema de relaçóes comerciais caracterizado pela dominação de um centro exportador sobre uma periferia importadora. Alguns países da Europa, com a nútida liderança da França no terreno cinematográfico, tornam-se centros produtores. Do outro lado do Atlântico, os Estados Unidos, já no início 146 do século, desenvolvem a indústria cinematográfica: tinbam tecnologia, capitais e mercado para isso, além doknow-bow específico, centralizado inicialmente na companbia de Edison, co-inventor do cinema ${ }^{20}$.

Nesse contexto, já não mais satisfazia os circos de cavalinbos e nem as peças encenadas no teatro: eram consideradas artes morosas, sem o glamour do moderno, do novo, enfim, sem movimento; além do que, na visáo dos modernistas, eram relacionadas diretamente aos costumes atrasados e a um passado não-moderno, não-urbano. Ao contrário, o movimento-desvendado pelo maquinismo e suas engrenagens, - era lembrado pelas máquinas incessantes nas linbas de produção, pelos transeuntes apressadosfrente aos apitos das fábricas que os lembravam o dever, pelos poucos automóveis que circulavam nas ruas estreitas do centro, pelo tic-tac do relógio.

Dessa forma se pode entender melbor o sucesso que fazia a projeção de uma película de cena muda: era a arte do movimento, era pois desprovida da retórica que amargava as peçasteatrais 
para, ao invés disso, fiar-se no movimento dos corpos, e tratar de temas que povoavam o cotidiano, de uma forma ficcional ${ }^{21}$.

Desde 1912 funcionavam no centro da cidade três cinemas: o Bijou Theatre, na rua SãoJoão, o Radium, na São Bento, eo Iris Theatre, na 15 de novembro. Nos bairros, o High Life e o Smart, na Vila Buarque, o Rio Branco e o Brasil em Santa Efigênia, e Edison e o Eden, na Luz, o Pavilbão dos Campos Elíseos, nos Campos Elíseos, o Iris, o Popular e o Piratininga, no Brás, e o Avenida, na Liberdade, inchuindo ainda as sessóes cinematográficas de graça proporcionadas por algumas confeitarias de luxo aos seusfregueses ${ }^{22}$.

O deslumbramento frenético pelo moderno e pela novidade, o desenvolvimento das tecnologias de lazer bem como os novos ritmos urbanos emergentes corroboram de certa forma para que o cinema seja visto como o corolário da modernidade, como a encarnação do futuro, pois consegue aliar todos os ingredientes que caracterizam esse novo tempo e se distancia cada vez mais das visóes de outrora:

Nós devemos ser bem maisfelizes que nossos avós. Não há dúvida que sim. Quanta coisa extraordinária que vemos boje não lhesfoi vedado sequer imaginar com ares de verossimilhança? $O$ automóvel, o aeroplano, opróprio trem de ferro... Nem precisamos ir a tanto no capítulo da mecânica, onde todo mundo já se cansou de fazer a enumeraçáo das maravilhas do séculoXX em contraste com o carro de bois, a mó, o monjolo de há setenta anos atrás. Em terreno menos delicado e espiritual, bá muito que respigar em idêntico sentido.

Jápensou alguém acaso, em quanto progredimos na esfera das visões? Nossas boas avozinhas, boas e belas como é fama que foram, teriam tido as mesmas ilusóes de nossas jovens contemporâneas? Náo decerto. As doces miragens de outrora, por muito mais que sempre valha o passado sobre o presente, náo valem em nitidez, em verdade e encanto, a mais mesquinha visão de boje, quando eles passaram a se fixar na tela do cinema. Que prodígios de imaginação não seriam então necessários para que vivesse a gente menos apegada à terra eàs coisas. -Há de pensar a leitora. E de fato deve ser isso mesmo ${ }^{23}$.

Aatitude de trazer ao alcance da visáo o que está distante, ou de fixar o que está próximo, consolida o poder de transporte da imagem no espaço e no tempo. Este transporte é correlato à nova 
experiência do espaço e do tempo proporcionada pelos novos veículos. Assim, o cinema, consentâneo com as mudanças que a nova sociedade industrial provocara no ritmo da vida cotidiana, privilegia a velocidade, a ação, o bom bumor. “(...) O cinema, assim como os bondes e os estádios, alinha multidóes de estranhos enfileirados ombro a ombro num arranjo tãofortuito e normativo como a linha de montagem. Os bondes, contudo, lhes dão mobilidade, os estádios estímulos, os cinemas fantasias e as linhas de montagem subsistência"24. As cobranças da vida moderna eram muitas e o cinema funcionava como o divertimento despretensioso, evocando aspectos que caracterizavam o status de bomem moderno como a esportividade, a aventura, a puerilidade, caminhando assim contrariamente às artes intelectualizadas, como por exemplo a literatura e o teatro.

(...) o tempo, o século são mais do cinema: rápido, sintético, capaz de reproduzir e concentrar as múltiplas e complicadas atividades da vida de hoje. O tempo, o século não são mais do teatro, ou pelo menos, do teatro como vem sendo praticado: lânguido, mórbido, cheio de preconceitos, de lugares-comuns, contrário, pois, ao espírito sadio, esportivo do momento, inadaptável à época atual, incapazde refletir a vertigem da nossa vida, de satisfazer ao nosso insaciável, inquieto, constante desejo de algo novo. Contra esse erro do teatro deve começar a reação $o^{25}$.

Após a I Guerra Mundial, a indústria cinematográfica norteamericana começava a se moldar seguindo a lógica industrial de produção e organizar-se em função do "sistema de estúdio". Começaram a produzir películas em série e a penetrar nos mercados externos, na Europa e sobretudo na América Latina. No Brasil, na década de 20, as películas exibidas nas salas de projeção eram em sua grande maioria norte-americanas. Houve, nessa época, uma mudança de eixo divulgador e precursor das influências de modernidade, urbanidade ecivilidade, passando da Europa, mais especificamente Paris, para os Estados Unidos, que representavam um mundo desenraizado das tradiçóes pesantes, das raízes aristocráticas, que privilegiavam o novo, o despretensioso, o moderno, obumour. 
Uma das modalidades da face ficcional do cinema passa a constituir o tema preferido dos intelectuais “modernos": a comédia burlesca, com sua agitação, correria e perseguições, será o foco do elogiado aliado à condenação do "teatrofilmado" ${ }^{26}$. A comédia traz consigo o movimento, o efeito de surpresa. Leitores dos periódicos sobre cinema, bem como dos jornais da época nos mostram seu favoritismo em relação ao gênero cômico, representado por um tipo de visão e postura perante os problemas e contratempos da vida moderna, servindo muitas vezes como "válvula de escape" para os problemas apresentados por essa modernidade contraditória:

O senbor, muito avançado em anos, que ontem à noite nos procurou para formular uma queixa, era exatamente como todos os senhores de sua idade e nas condiçóes. Por isso, não nos surpreendeu. Nem mesmo quando afirmou, com uma serena convicção, que o 'bomem é o único animal que rí'. Dito isto, pôs-se o queixoso a desenvolver a sua tese. veio desde o engraçadíssimo Noé, nu alegrote, dando pinotes, babando e tropeçando nas barbas, com escala em Rabelais, até Jerome K. Jerome do Three men in a boat e afinal, até os filmes cômicos americanos. Falounos da bumana necessidade de désopiler la rete sem pílulas do Reuter nem cócegas com pena de galinba na planta do pé. E assim, atingiu o seu alvo: Reclame, sr. redator, reclame em nome de todos os biliosos e a bem da saúde pública, contra o desleixo dos nossos importadores e exibidores cinematográficos, que não contentes com interromper o comércio dos bons filmes cômicos, deixam até de anunciar nos jornais e nos seus placards as pequenas de que ainda dispóem. Isto é uma desgraça. Dou a vida pelas comédias: elas eram para mim, nospesados pratarrazes dos dramas e tragédias, uma gota de molho, uma pevide de pimenta; ou às vezes, depois deles uma sobremesa ligeira, esse pequenino torráo de açúcar que adoça a boca, suaviza a vida e reconcilia a gente com as coisas tristes deste mundo. Lembro-me, com saudade das pilhérias de Max Sennett, do Christie, de Mutt eJeff, do Gato Félix... Realizavam os absurdos, os impossíveis, as infantilidades que a nossa imaginação cansada de letras de câmbio e discussóes políticas exigia e o nosso organismo reclamava. Pensei, nesses últimos tempos, que houvesse nos Estados Unidos, uma crise de bumour, uma decadência do riso. Engano. Sei agora, pelo contrário, que há na América do Norte, entre muitas outras, uma instituição altamente humanitário, que se chama Educational's Comedies (note bem: educational), considerada pela gente saudável de lá the spice of the program. Alistam-se nela produções 
inúmeras se inúmeras fábricas: Hamilton Comedies, Lupino Lane Comedies, Bobby Verno Comedies, Billy Dooleuy,Jimvery Adams, Tuxedos Comedies etc etc: preciosidades que nem sequer de nome são conbecidos aqui. No entanto, ninguém mais do que nós precisa desses calmantes: 'Flor amorosa de três raças tristes...' Reclame sr: redator, reclame ${ }^{27}$ !

Mais especificamente em relação à literatura, ocinema tratou a narrativa literária romântica e seus temas recorrentes de uma forma moderna, ou seja, a fantasia, a ficção, o bappy end eram representados no cinema em bistórias que encantavam eprendiam a atenção do público, distanciando-se assim do realismo literário, que trazia temas que, ao contrário do cinema, retratavam a problemática das doenças, das tristezas, e tudo que era inerente a essa vida moderna. Além disso, omercado editorial estava tomadopor um tipo de literatura que vinba substituir a de cordel, que vinba modernizar seusleitores, coetânea das novastecnologias de lazer e promotora de um status diferenciado e moderno por parte de quem a consumia. Estamosfalando das magazines:

Veja oss: -dizíamos, cortando a R. Direita, naquelatarde arrepiada de huvas e pullover, ao imaginário gerente de uma grande empresa cinematográfica - veja o sr. como em S. Paulo se lê cinema. Para todos estes agentes de jornais o melhor negócio agora é a revista norte-americano do movie. E isto vem de longe: vem dos tempos tão saudosos da linda Shadowland que os vendedores traduziam 'chá da Holanda'... Agora, outros muitos inúmeros Magazines tomaram-lhe olugar: Photoplay, Classic, Picture Play, Motion Pictures, (...), hoje a nossa literatura de cordel. Substituí com vantagem o romance policial que ensinava aos pequenos e aos grandes-com terrível inquietude dos pais assustadose dospatrões medrosos-a maneira mais prática, rápida e eficazde se arrombar um cofre, esquartejar um cadáver, incendiar uma cidade... Enão pense que isto é só 'para inglês ver' ou 'ler', não. Nós todos já lemos e entendemos decentemente a maviosa lingua cineautomobilística de Cecil B. De Mille e Henry Ford. Vá aos halls de nossos clubs ou dos nossos botéis, ao living-room dos nossos lares, ao pulman-car das nossas estradas de ferro, aos bondes da nossa Light! Todo mundo está lendo uma fan-magazine. $E$ entende. E gosta. (Você, leitor, repara um pouco nas aspas incomodativas que estão estrangeirando este monólogo, influência das revistas de cinema-acredite) ${ }^{28}$. 
É interessante notar que o cinema, enquanto disseminador de bábitos e criador de moda foi muito mais eficiente do que qualquer outro veículo que se propôs exclusivamente a isso na época, tanto assim que jornais e revistas especializadas cada vez mais abriam espaço, náo só para fazer a crítica ou a chamada de um filme, mas principalmente para fazer perpetuar, pormeio das lembranças das imagens de certa cena, alguns produtos ou costumes. A ditadura da moda veiculada pelo cinema bollywoodiano e seus atores sobre o senso comum é comprovada quando se verifica a construçáo de verdadeiros manuais de moda ditados pelo Star System bollywoodiano, passando a ser a maisforte arma de propaganda para o consumo de objetos, roupas, perfumes, como por exemplo, o gomex dos cabelos de Rudolph Valentino, ou ainda os modelos de maiôs de praia usados pelas atrizes em cenas maisousadas.

Oque particularmente se verifica é uma sociedade que pretendia se jovializar e se bomogeneizar através da cultura de massas, onde roupas, chapéus, sapatos, meias, casacos de pele, frasqueiras, estolas tendiam a ser padronizados segundo modelos europeuse norte-americanos. Asjovensfumavam, falavam com determinaçãoe náomaisse interessavam pela estereotipada 'feminilidade"tradicional: elas se consideravam independentes. "Aquelas garotastolasem seussintéticos sonboshollywoodianos, em seuspatéticos batonse meias de seda, em suas imbecis frivolidades"29.

O terrivel problema nasceu no Paraíso com Adão e ainda é discutido e ainda nãofoi resolvido. Da primitiva tosca tanga de folhas de figueira à mole, quente e neutra flexibilidade da flanela pinky-buff, vão milbares de séculos de graves cogitações e inúteis experiências. Cada época vem dando ao problema uma solução provisória a que se dá o nome de moda. E apresenta um manequim. Alcebíades, Petrônio, D'Artagnan, Leandre, D'Orsay Brummel, Morny, Fouqueères, Lord Lousdale -foram manequins estimáveis no seu tempo. Ora, o nosso tempo é o do cunema, e o cinema é dos Estados Unidos, e os Estados Unidos têm Hollywood e Hollywood é a capital do filme: - logo, ab! Na metrópole do Reino da celulóide devemos procurar o arbiter elegantiaruam. Árbitro evidentemente das elegâncias masculinas, asfemininas náopodem ser tratadas decentemente neste capítulo de absoluta seriedade. Em Hollywood, odedo sábio dos entendidos aponta a um só bomem: Conrad Nage ${ }^{30}$. 
Nas décadas de 20 e 30, a divisão sexual do trabalbo e a consciência das mulheres sobre elas mesmas estavam mudando. Surpreendentemente, a publicidade e o cinema, jogando com a fantasia e a excitação, permitiram que as mulberes imaginassem um fim para o enfadonbo trabalbo doméstico e para o desejo crônico. Imagens de cozinhas e eletrodomésticos modernos e de roupas e maquiagens bonitas e baratas em cartazes, telas de cinema, e nas novas revistas femininas, acrescentavam nova dimensão ao romantismo.

Os anúncios das principais revistas brasileiras mostram que algumas casas das primeiras décadas do séculojá estavam bem aparelhadas. Com a eletricidade, "já se podia substituir oferro de passar aquecido com brasas e obter gelo para conservar os alimentos. De acordo com a condição de riqueza, a dona de casa poderia escolber otipo de fogão, a lenha, a carvão, a gás, elétrico ou a querosene; a indústria começava a beneficiar e a produzir muito dos alimentos que antes eram elaborados em casa". Apesar da aparentefacilidade, traduzida porumagamavariada deapare152 lbos elétricos oferecidos ao público e por anúncios, nos quais as mulberes executavam os mais difíceis e sujos serviços domésticos "sempre sorrindo". Os novos bens de consumo beneficiaram apenas uma parcela da população, composta daqueles que podiam pagar e aqueles que se decidiram pela novidade, já que a relação dos consumidores com o novo náofoi automática e nem sem conflitos ${ }^{31}$.

Apesar do desejo de muitos intelectuais e profissionais das camadas dominantes de espelhar homens e mulheres brasileiros pelas imagens da burguesia das duasmaiores cidades doperiodoRio de Janeiro e São Paulo, as capitais do progresso -, essa não era a realidade vivida pela grande maioria de brasileiros. Os padróes de comportamento burgueses, a modernidade e o consumoforam absorvidos de forma desigual pelas diferentes regióes e cidadese pelas diferentes camadas da população. Grande parte do paíspermaneceu fiel à agricultura, seja sob a autoridade dos ricosfazendeiros, proprietários de grandes plantações, onde em geral era cultivado um único produto para exportação; seja como morador das pequenas propriedades, cujo número vinba crescendo desde 
o século anterior. Nem todas as cidadespuderam realizar a modernização desejada. Em razão da falta ou do mau uso de capitais. A industrialização, por seu lado, embora tenba deslocado progressivamente a produção para fora do domicílio, não destruiu de uma só vez as formas tradicionais de produção e sobrevivência ${ }^{32}$.

Juntamente com os serviços domésticos realizados de maneira dura e tradicional, a maioria das mulberes que viviam relações conjugais consensuais, sem uma presença masculina efetiva no lar, ou convivia com companheiros que náo tinham trabalbo nem efetivo, nem regular, cuidavam dos filbos e exerciam várias atividades ao mesmo tempo para prover a própria subsistência e dafamilia ${ }^{33}$. Muitas dessas atividades eram extremamente pesadas, em nada correspondendo à imagem dos papéis femininos idílicos representados nas telas, como a derrubada das matas, a construção civil, além de outras mais conbecidas, como o trabalho temporário nas indústrias têxteis, o artesanato doméstico eo pequeno comércio ambulante ${ }^{34}$.

É certo que, com o desenvolvimento industrial e urbano, o acesso a uma melbor escolaridade, a divulgação pela imprensa de uma participação maior das mulberes no espaço público depois da Primeira Guerra, sobretudo na Europa e Estados Unidos, o avanço do feminismo e as freqüentes reivindicaçóes das mulberes pormaiores oportunidades acabaram por abrir algumas novas profissóes para as brasileiras for a do lar. Esse progressofeminino, no entanto, precisa ser tomado com cautela, uma vez que bavia certos limites para a aspiração feminina, as ofertas disponiveis, em geral, estavam próximas daquilo que se considerava uma extensão das atribuições das mulberes: professora, enfermeira, datilógrafa, secretária.

Influenciadas pelos novos papéis femininos representados nocinema, as mulberes tinham esperança de viver "vidas diferentes" das de suas mães. As principais ruas de comércio na cidade começaram seu reinado como o centro da moda tanto para as mulheres da elite quanto para asjovens das classes médias e operárias-o local adequado para sua nova e tão ostentada condição de feminalidade cosmopolita. As costureiras de roupas finas continuavam apresentando os caros cetins e brocados; e as vitrines ainda 
exibiam nos manequins suas roupas perfeitamente drapeadas. Mas a alta moda náo conseguia deter a imaginaçấo dasjovens. As imagens imitativas de Jean Harlow, Greta Garbo eJean Crawford desfilavam pelas principais ruas quando elas brilhavam nastelas de cinema. Porém, poucas podiam comprar ou encomendar as novas roupas em lojas elegantes.

Entre as mulberes menos favorecidas, as mães, irmãs e amigas estreitavam seusvínculos de sociabilidade e solidariedade trocando modelos e apressadamente copiavam o vestuário das estrelas utilizando materiais baratos adquiridos em feiras ou lojas de departamentos igualmente baratas. Essas relaçóes de produção/reprodução cultural que se dão no cotidiano nos deixa entrever a relação entre consumo e produção cultural, baseando-se no fato de que "o consumo cultural de massas caracteriza as sociedades ocidentais a uma produção racionalizada, expansionista, tanto quanto centralizada, estrondosa e espetacular, corresponde uma outra produçáo qualificada de consumo". Dessa forma o consumo cultural é tomado, ele próprio, como uma produção, que evidentemente náofabrica nenbum objeto, mas constitui representações que nunca são idênticas às que o produtor, o autor ou artista, incutiram na sua obra. Esta produção é ardilosa, encontra-se dispersa, mas insinua-se por toda a parte, silenciosa e quase invisível, uma vez que não assinala a sua presença com produtos próprios mas com 'maneiras de utilizar' os produtos impostos por uma ordem economicamente dominante ${ }^{35}$.

Nesse sentido, é emblemático um dos contos de Antônio de Alcântara Machado, que mostra esse processo de absorção e reinvenção dos sígnos culturais bollywoodianos:

A rua Barão de Itapetininga é um depósito sarapintado de automóveis gritadores. As casas de modas (Ao Chic Parisiense, São Paulo-Paris, Paris Elegante) despejam nas calçadas as costureirinhas que riem, falam alto, balançam os quadris como gangorras...(...) o vestido de Carmela coladinho no corpo é de organdi verde. Braços nús, colo nú, joelhos de fora. Sapatinbos verdes. Bago de uva Marengo maduro para os lábios dos amadores reflete a boca reluzente de carmim primeiro, depois o nariz chumbeva, depois os fiapos de sombrancellha, por último as bolas de metal branco na ponta das orelhas descobertas...(...) Deante de Álvares 
de Azevedo (ou Fagundes Varela) o Angelo Cuoco de sapatos vermelbos de ponta afilada, meias brancas, gravatinba deste tamanbinbo, chapéu à Rodolfo Valentino, paletó de um botão só, espera bá muito com os olbos escangalbados de inspeccionar a ruabarãode Itapetininga ${ }^{36}$.

A influência docinema bollywoodiano no Brasil, decisiva para a construção de uma cultura cosmopolita de fachada, enveredouse por vários caminbos: substituiu a coroa dos reis pela auréola efêmera das estrelas da terra, construindo um mundo idealizado e romântico, onde a moda e os costumes passaram a ser apreendidos náo mais na tradiçáo familiar ou no contato com os meios tradicionais de educação (escola, igreja, catecismo etc), mas antes por intermédio de uma grande tela, que figurava um mundo novo a ser imitado.

É de temer-se, no entanto, que seguido sempre o mesmo rumo cheguemosà mesma situação de bipertrofia imaginativa para unse obturidade para outros. Taléa obsessão cinematográfica. Nãofalta porcáquem viva para ocinema, banalizado e materializadoassim comoo arroz doce e a marmelada. Não escasseiam também os que, nãocontentes comisso, vivem para além dastelase dasfitas... Cúmulo daabstração, armando-se emlindas cabecinhascinematógrafosideais em que se projetam - projeções de projeções - reminiscências de filmes e vidas inteiras de atores e atrizes, mediocres e nulos na generalidade. Enesses cinemas de cinemas, onde bá sempre a meialuze a lâmpada misteriosa de uma idéia central, rompem dramase paixóes rebentam, como no outro cinema.

Há quem prosseguindo nesse ardor, traga ao peito medalbóes com beróicas efigies norte-americanas... E-ómaior de santabisavozinhas que se foram morrendo no seu quarto, ao pé do sagrado nicho da Senhora das Dores! - Existem mais quem traga à cabeceira, em lugar do antigo Santo Antonio, o descabelado retrato de George Walsh ${ }^{37}$.

Avulta nas crônicas cinematográficas da época temáticas do universo feminino, pois é indiscutível que o universo cultural bollywoodiano, já nessa época, representava fonte inexaurível de padrões de bábitos, costumes, comportamentos, valores, moda; enfim, de um modus vivendifeminino. É emblemático dessa influência o episódio escrito por Blaise Cendrars em um de seus contos, entitulado "As negras louras" em que ele conta que estava no Brasil na época em que saiu a A Vênus Platinada, filme 
(...) que fez tal sucesso no Rio de Janeiro que em menos de uma semanatodas as belasmulatase asnegras indolentesquesaem para passearnofim datarde na Avenida ou para desfrutar do arfrescò̀ beira-marna praia do Flamengo, baviam mandado descolorir os cabelose semaquiavam todas de cor-de-rosa. (...)Eratãoengraçado! Masera aomesmo tempo inquietante, poistodas elaspareciam não ser mais que o avesso delas mesmas como esses personagens que entrevemos por transparência quando examinamosum negativo a olbo nu. Imagine só aquele cortejo de negras louras à luz do crepúsculo, à contraluz, com a nódoa clara de seu rosto maquiadoe seuscabelosmortos, masbrilhantes! Um cortejodefantasmas, poderse-ia dizer: Um dia cheguei a encontrar uma negra quetinbatingido os cabelos com bena e exibia o mais belo ruivo irlandês. Era uma criatura soberba, masruiva, soberbamenteridícula ${ }^{38}$.

O cinema, segundo Mário de Andrade, "a criação artística mais representativa de nossa época” parece também emergir extremamente sintonizado com os discursos "modernos" que conformam o perfil da mulher. Como exemplificar ofascínio e o pânico frente às imagens das novas divas das telas, envoltas numa aura de sedução e perigo que as novas câmeras do cinematógrafo criavam? Oclose-up, inovação permitida pelas novas técnicas do cinema, bem como o "embrulbar no negro" das salas de exibição passam a definir o papel prioritário do cinematógrafo enquanto instrumento de sondagem da alma e das zonas escondidas da vida cotidiana Num dos primeiros textos sobre cinema, Hugo Munsterberg compara a ampliaçáo possibilitada pelo close-up ao momento em que "no auge da emoção no palco o espectador de teatro recorre aos binóculos para captar a sutil emoção dos lábios, a paixão ou o terror expressos no olhar, otremor das faces". $E$ ' essa arte da modernidade que traz em sua natureza a marca de um olbar fortemente erotizado que vai produzir, num mundo bermeticamente fechado e onírico, as imagens e os mistérios das estrelas do nosso cinema ${ }^{39}$.

Porsua vez, a denominação "estrela", emprestada especificamente às atrizes do cinema, procura recuperar ovalor de cultoperdidopela ausência da presença fissica no palco, investindo nos sentidos de exílio, distância e inacessibilidade que o termo permite. Na política do estrelismo, modelo do sucesso implantado pela indústria de Hollywood e divulgadopelas revistas cinematográficas ame- 
ricanas e nacionais, dois eixos discursivos orientavam a imposição de um padrão de beleza e de atração exercido pelas atrizes (e atores) na conquista do público: a lei dos tipos e a fotogenia. A elas somava-seo "espectro característico", definidor da personalidade dos artistas e articulador dos predicados indispensáveis à conquista de um lugar de destaque nofirmamentocinematográfico ${ }^{40}$.

As estrelas de cinema, cuja vida particular fora das telasé sinônimo de veneração e bisbilhotagem, despertava o interesse da platéia frente a seus hábitos mais corriqueiros, a fim de imitarlhes também na vida real. Os padróes estéticos que ditavam os contornos do corpo feminino também sofrem a inferência dos modismos ditados pelo cinema:

Uma revista americana de cinema estuda, com uma curiosa documentação fotográfica, a transformação que sofreu, nesses últimos trinta anos, o corpo das mulheres e, consequentemente, o gosto dos homens... Entre as velhas fotografias de camarim, do século $\mathrm{XIX}$-com mulheres opulentas de corpos esmagadores cheios de lantejoulas, de cabelos, de pernas garrafa-de-Champagne e de meias altíssimas, postadas sobre cenários de um falsidade grotesca (bambinellas, veludos adamascados, passamanariase galóes); entre esses retratos que todos os nossos tios solteiróes tinham escondidos nas suas gavetas de camisas engomadas, cheirosas a vetier, o magazine exibe, para confronto, três silhuetas atuais: Dolores Costello, Gilda Gary e Marie Prevert. O contraste é brutal. Ali, volumes; aqui, linhas. Ali, rotundidades inúteis, exuberâncias incomodativas; aqui, traços simples, nítidos, esportivos, nervosos. Ali, masurka; auiblack-bottom. Quem sáo aquelas grandes, importantes, não-microbianas pessoas do século de Edison? Uma é Irene Verona (apertada num corselet de cetim, altos coturnos, um espadim na máo: parece uma amazona de circo). (...) Todas elas, gordíssimas e abundantíssimas, fizeram furor no seu divertido e enfeitadofim-de-século. Pergunte aos porteiros dos teatros ou ao seu papá quantos ramalhetes catitas, dentro dos cartuchos de papel rendado, eles não receberam, na portinhola deflacre, dos belos leóes empornadados, frisados, cheirosose Jicky, cosméticos e eles de Orisa... Hoje, nós estranbamos aquelas excessivas superabundâncias: achamo-las todas parecidas com esses cromos lustrosos da follhinha, esses anúncios espalhafatosos de cerveja, em que há sempre uma diva montada sobre uma garrafa... E pensamos logo em champagnadas soturnas com danças em cima de mesas e madrugadas azedas... O esporte, as danças modernas, a condenaçấo pela moda, do espartilho de barbatanas 
e dos saltos altos -tudo isso havia de esperar a metamorfose por que passaram os corpos desses ídolos reincarnados agora na finura quebradiça, estilizada, quase irreal dasfrágeisfigurinhas de hoje ${ }^{11}$.

Revistas especializadas da época, comopor exemplo a Cinearte, tentam difundir um modelo de atração e sensualidade uniformizador das preferências dosfãs: "It", "sex-appeal", "sofisma”, “malícia”, “personalidade”, "spleen”, idéiaschavesdisseminadas pela mídia americana e que apresentam popularidade entre nós ${ }^{42}$. Por volta dos anos 20 , juntamente com a evolução técnica do cinema e o aperfeiçoamento de sua linguagem, os paradigmas que constituem a lei dos tipos, ou seja, a "Vamp", a "Ingênua" e a "Flapper" (a maliciosa) também procuram se modernizar. Assim “(...) a 'Vamp' brasileira, ainda que retivesse o significado de ameaça e a atmosfera de irresistível sedução, tradicionalmente seu traço identificadornão se diferencia muito da "flapper", insinuante "protótipo moderno", babituada ao "sofisma" e a "malícia", como se dizia na época"ł3. Nasfitas a vamp-moderna usa roupas de Paris, dirige carros em alta velocidade, joga tênis, dança, fuma, bebe "gin",

158 sendo seu maior veneno demolidor sua própria característica enquanto personagem feminino, pois desestabiliza a família e desafia os preceitos da moral cristâ, sendo mesmo "um contraponto aos costumes 'modernos', sugerindo uma liberdade um pouco excessiva e conseqüente questionamento dos preceitos sociais.

Otipo “Vamp”, forma abreviada devampiro, traduzinvariavelmente um sentido de ambigüidade entre a vida e a morte, a noite e o dia, a sombra e a luz, a sexualidade e a punição, o vampiro não pode ver seu reflexo, não consegue jamais ter a sua própria imagem refletida no espelbo, pois no espelbo só aparece o outro, ou seja, só se torna possível olhar para si mesmo por meio da mediação do outro ${ }^{44}$. É precisamente essa ambigüidade, a de ser o reflexo do olhar do outro, que a elege como o “tipo" por excelência de invenção de uma indústria cultural emergente e torna possível a projeção das ansiedades de um tempo.

Paralelamente à ascenção do star system, bouve uma alteração nos temas dos filmes hollywoodianos. Um exame dos enredos listados nos maiores jornais de comércio de 1907 a 1919 revela uma mudança aguda. De 1908 a 1912 os photoplays feitos 
por independentes tinham temas vitorianos, tornados populares por Griffith. Pouco tempo depois, a tradição anglo-saxônica passou a ser questionada e cada vez mais os enredos apresentavam personagens que caiam em pecados antes atribuídos a estrangeiros, vilóes ou aristocratas. Geralmente, o berói ou a beroína superava perigos como bebida, gastos em excesso e mulberes sensuais.

Afigura da "Vamp" foi muito popular principalmente entre os anos de 1914 e 1916 nas produções hollywoodianas, sendo a maisfamosa Theda Bara que, ao contrário dasjovens virgens loiras do período anterior, era voluptuosa e morena. Bara interpretou Cleópatra, Salomé e Madame de Pompadour, mulheres cuja fascinação erótica destruíram bomens que dominavam vastos reinos. A "Vamp", portanto, incorporava o mais eminente dos avisos dos cruzados anti-vícios: o sexo pode destruir a ordem social ${ }^{45}$.

Era muito claro que as mulheres estavam reelaborando seus papéis dentro da sociedade moderna. As revistas de fã apresentavam repetidamente artigos sobre jovens mulheres e as identificavam com a juventude e a modernidade em si. A cultura de massas, especialmente o cinema, apelava para essa imagem feminina, pois ela se opunha frontalmente às mulheres do lar provinciano, arcaico, e representava antes de tudo a mulber moderna, que trabalha fora e que participa ativamente da vida pública.

Os novos critérios da fotogenia, "valor essencial" da imagem luminosa projetada na tela, passam a definir opadráo de beleza feminina proposto pelas revistas de cinema e disseminado pelos primeiros concursos de Miss Brasil, em profunda sintonia com a política eugênia que permeava o debate civilizatório nacional. “(...) a quase totalidade dos filmes brasileiros produzidos na época do cinema mudo revelam o subtexto que articula a "perfeição racial" com a "aptidáo para o cinema" e com a adequação aos “temposmodernos" . Ainda segundo Ismail Xavier "a fotogenia, indicadora do específico cinematográfico e depósito de suas verdades mais profundas, transforma-se em atributo poético de em conceito epidérmico de beleza, associado a hxo, higiene ejuventude (...)”. Combinando aspecto característico, fotogenia e lei dos tipos, temos o tripé de um modelo aristocrático de perfeição racial e da preferência estética pelos bem dotados, sendo os povos 
divididos entre os que tem charme e os que não têm. Evidentemente, o impulso "patriótico" sempre colocou o Brasil, sua natureza e a parcela branca e rica de seu povo, como um país apto para ocinema e para a modernidad $e^{47}$.

Ascrônicas da época que falavam decinema, bem comoascolunas de jornais que possibilitavam uma interação direta com osleitores, mostram-se boje comoverdadeiros manuais do protótipo cultural e estético da moçajovem da década de 20 , além do que estigmatizava emarginalizava aquelaque náocorrespondia a esse ideal:

Imagino que você seja - minha cara leitora - um pequenino tipo destes tempos: um espírito inquieto dentro de um vestido inquietante... Imagino bem simplesmente que você seja apenas uma absoluta young girl in the teens... quero dizer - que você saiba dar a seus tweeds matinais uma geométrica atitude de esporte, que você náo acredite mais na utilidade da cabeleira dourada de Lady Godiva e que, por isso, a sua cabecinba bem boyish não preocupa mais a sua alminha bem dirigida; que você já fingiu beber, por uma tarde, uma xícara de chá no Ritz... e que você ainda é aquela mulherinha bem inocente, bem peccadille colegial das cóleras de notre mèrel; e que você gosta de vestir, de noite, qualquer crepe-cetim de um baby-blue inofensivo de nursey, $e$ sabe então dizer il pleut de um maneira tão especial... Entretanto, com tudo isso, você me confessa um absurdo que eu me recuso a aceitar: você náo gosta de cinema. Se isto fosse verdade - minha mentirosa leitora-todas aquelas coisas tão present-day, tãolindas, tãofinas que existem em você, desapareceriam (...) ${ }^{48}$.

Em uma situação de muitas mudanças - a despeito de algumas permanências - nos padróes de vida no início deste século, o cinema desempenhou um papel importante na consolidação de status e de valores de referências, exercendo importante influência a o divulgar e consolidar comportamentos e influenciar numa certa domesticação de gostos e costumes. Entretanto, ele só pôde desempenhar esse papel porque respondia, ao mesmo tempo, às necessidades do discurso de legitimação do projeto civilizador das elites paulistanas è̀s necessidades dessa populaçáoformada por imigrantes e migrantes desenraizados. “(...) os personagens desse mundo em ebulição carecem, com urgência, de um eixo de solidez que lhes dê base, energias e um repertório capaz de impor sentidos a um meio intoleravelmente inconsistente" ${ }^{\text {"49 }}$. 
Assim, o cinema teve ação relevante na urbanização da cidade de São Paulo, utilizado sobretudo como um precioso instrumento de intervenção social na elaboração do "novo bomem", do bomem moderno e civilizado, consentâneo com o ritmo de vida urbana e industrial, de uma nação bomogênea, bigiênica, moralizada e disciplinada, estabelecendo com seu público uma relação circular, de influência mútua e troca de informações no jogo cotidiano da reelaboração. Dessa maneira, o caráter normativo ou ideológico das representações criadas no cinema é sempre filtrado pelo uso que delas fazem os espectadores ${ }^{50}$. Se é certo que o cinema constitui um sistema de poder simbólico que legitima a ordem social existente, não é menos certo que os sentidos que produziu variaram de acordo com os mais diversos grupos que se formavam na cidade e que sua recepção dependeu do embate constante entre o discurso normativo e a inventividade de suas práticas cotidianas.

\section{NOTAS}

${ }^{1}$ SEVCENKO, Nicolau. Orfeu Extático na Metrópole, São Paulo sociedade e cultura nos frementes anos 20. São Paulo, Cia das Letras, 1992, p.255.

${ }^{2}$ LOTITO, Marcia Padilha. A cidade como Espetáculo: Publicidade e Vida Urbana na São Paulo dos anos 20. Dissertação de Mestrado,São Paulo, FFLCH-USP, 1997, p.04.

${ }^{3}$ SEVCENKO, Nicolau. op. cit., p.31.

${ }^{4}$ GALVÃO, Maria Rita Eliezer. Crônica do Cinema Paulistano. São Paulo, Ática, 1975.

${ }^{5}$ LOTITO, Marcia Padilha. op. cit., p.07.

${ }^{6}$ GALVÃO, Maria Rita Eliezer. op. cit., p.17

${ }^{7}$ PINTO, Maria Inez Machado Borges. "Historiografia Contemporânea da Cultura Popular: Tendências e Impasses”. In História em Debate: Problemas, Temase Perspectivas. Anais da XVI ANPUH. Rio de Janeiro, CNPq/Infour, 1991.

${ }^{8}$ SEVCENKO Nicolau. op. cit., p.18.

${ }^{9}$ FABRIS, Annateresa. O Futurismo Paulista. São Paulo, Perspectiva, 1994.

${ }^{10}$ AMARAL, Araci. Blaise Cendrars no Brasil e os modernistas. São Paulo, Martins Fontes, 1970.

${ }^{11}$ Jornal do Comércio, 23/01/1921.

${ }^{12}$ Correio Paulistano, 02/02/1921.

${ }^{13}$ FABRIS, Annateresa. op. cit.

${ }^{14}$ CARVALHO, Ronald de. "Os independentes de São Paulo”. In BATISTA, M. Rossetti. Brasil: 1 Tempo Modernista 19/07/1929. Rio de Janeiro, Tempo Brasileiro, 1972. 
${ }^{15}$ ANDRADE, Oswald de. "Reforma Literária”. In Jornal do Comércio. Sáo Paulo, 19/05/1921.

${ }^{16}$ HABERMAS, Júrgen. Mudança Estrutural da Esfera Pública. Rio de Janeiro, Tempo Brasileiro, 1984, p.189.

${ }^{17}$ SEVCENKO Nicolau. op. cit., p.28.

${ }^{18}$ PINTO, Maria Inez Machado Borges. "A cena muda: maquinismo e lazer na metrópole cafeeira, 1910-1930”. In Anais do X Simpósio de História - Edição Especial da Revista de História no 05. Vitória, UFES, 1997, p.17.

${ }^{19}$ SEVCENKO Nicolau, op. cit., p.245.

${ }^{20}$ PINTO, Maria Inez Machado Borges. op. cit., p.17.

${ }^{21}$ FERRARESI, Carla Miucci. "Onascimento de uma cidade: cinema bollywoodiano no processo de cosmopolitização paulista”. In Revista Vir-a-Ser. São Paulo, Humanitas, $n^{\circ} 01,1996$.

${ }^{22}$ ANGERAMI, Domingos e FONSECA, Antônio. Guia do Estado de São Paulo (1912). São Paulo, Edifel, 1976, pp. 210 e 222.

${ }^{23}$ O Estado de São Paulo, 05/05/1920.

${ }^{24}$ SEVCENKO Nicolau. op. cit.

${ }^{25}$ O Estado de São Paulo, 16/07/1927.

${ }^{26}$ PINTO, Maria Inez Machado Borges. op. cit., p.18.

${ }^{27}$ O Estado de Sáo Paulo, 08/06/1927.

${ }^{28}$ O Estado de São Paulo, 21/05/1927.

${ }^{29}$ SOMMERFIELD, John. May Day. London, Oxford University Press, 1960, p.30.

$162 \quad{ }^{30}$ O Estado de Sáo Paulo, 05/05/1927.

${ }^{31}$ MALUF, Marina e MOTT, Maria Lúcia. "Recônditos do Mundo Feminino". In SEVCENKO (org.). História da Vida Privada no Brasil República: da Belle Époque à Era do Rádio. São Paulo, Cia. das Letras, 1998, p. 403.

${ }^{32}$ Idem, p.400.

${ }^{33}$ DIAS, M. Odila L. S. Quotidiano e Poderno séculoXIX. São Paulo, Brasiliense, 1995.

${ }^{34}$ PINTO, Maria Inez Machado B. Cotidiano e Sobrevivência: A vida do trabalhador pobre na cidade de São Paulo, 1890-1914. São Paulo, Edusp, 1994.

${ }^{35}$ PINTO, Maria Inez Machado Borges. op. cit., 1991.

${ }^{36}$ MACHADO, António de Alncântara “Carmela”. In Brás, Bexiga e Barra Funda: notícias de São Paulo. Belo Horizonte/São Paulo, Itatiaia/Edusp, 1988.

${ }^{37}$ O Estado de São Paulo, 05/05/1920.

${ }^{38}$ CENDRARS, Blaise. "As negras louras". In Hollywood 1936. São Paulo, Brasiliense, 1990.

${ }^{39}$ HOLLANDA, Heloísa B., BICALHO, M.F. e MORAN, P. "Vamps, ingênuas e flappers”. In Quase catálogo 3 - Estrelas do cinema mudo-Brasil, 1908-1930. Rio de Janeiro, CIEC/Escola de Comunicação/UFRJ/MIS, 1991.p.o8.

${ }^{40}$ XAVIER, Ismail. Sétima Arte: um culto moderno. São Paulo, Ed. Perspectiva, 1978.

${ }^{41}$ O Estado de São Paulo, 28/09/1927.

${ }^{42}$ HOLLANDA, Heloísa B., BICALHO, M.F. e MORAN, op. cit. p. 09.

${ }^{43}$ Idem, p.10. 
${ }^{44}$ CAMARGO, M. L. Barros. Atrás dos olhos pardos. Tese de Doutorado, São Paulo, FFLCH-/USP, 1990.

${ }^{45}$ LARY, M. Screening out Past. The Birth of Mass Culture and the Motion Picture Industry. Chicago, The University Chicago Press, 1980- Cap. 08 "Politica Dissolved: Cecil B.De Mille and the Consumer Ideal, 1918-1929”.

${ }^{46}$ HOLLANDA, Heloísa B., BICALHO, M.F. e MORAN, op. cit., p.14.

${ }^{47}$ XAVIER, Ismail. op. cit., p.180.

${ }^{48}$ O Estado de São Paulo, 18/07/1927.

${ }^{49}$ SEVCENKO, Nicolau. op. cit., p.31.

${ }^{50}$ CERTEAU, Michel de. A invenção do Cotidiano. Petrópolis, Vozes, 1994, cap.03. 
